\title{
Pulmonary Tuberculosis with Fixed Drug Eruption to All First-Line Anti-Tuberculosis Drugs
}

\author{
Tüm İlk Seçenek Antitüberküloz İlaçlarına Karşı Fiks İlaç Döküntüsü Gelişen \\ Akciğer Tüberkülozu
}

Gina Amanda, Fariz Nurwidya, Fathiyah Isbaniyah

\begin{abstract}
Tuberculosis (TB) is still one of the leading causes of mortality worldwide. Treatment with anti-TB drugs sometimes results in side effects for patients, including drug reactions, both allergic and non-allergic. Cutaneous adverse drug reaction is the most common side effect of anti-TB drugs, but severe reaction is rare. Here, we report rare case of a 34 -year-old male who presented with pulmonary TB and fixed drug eruption to all first-line anti-TB therapies. After ingesting anti-TB regimen, multiple skin erosions and blisters occurred. Skin biopsy was performed and result was epidermis with subepidermal bullous. The patient's condition deteriorated, he developed severe hypoxemia, and unfortunately, he died during fixed drug eruption treatment.
\end{abstract}

Key words: Adverse drug reaction, anti-tuberculosis drugs, drug eruption, tuberculosis.

\section{Özet}

Tüberküloz tüm Dünya'da önemli bir mortalite nedeni olmaya devam etmektedir. Antitüberküloz tedavi sırasında kullanılan ilaçlarla, allerjik veya non-allerjik reaksiyonlar şeklinde yan etkiler ortaya çıkmaktadır. Ciddi reaksiyonlar nadir görülmekle beraber, ilaca bağlı cilt reaksiyonları antitüberküloz ilaçların en sık görülen yan etkileridir. Burada, ilk seçenek antitüberküloz ilaçların tümüne karşı fiks ilaç döküntüsü olan akciğer tüberkülozlu 34 yaşındaki erkek olguyu sunuyoruz. Antitüberküloz ilaçların alımından sonra hastanın tüm vücudunda çok sayıda erozyon ve kabarcıklar oluştu. Cilt biyopsisi yapıldı ve sonucu epidermal ve sub-epidermal büller olarak tanımlandı. Hastanın durumu ağır hiposemi nedeniyle kötüleşmeye başladı. $\mathrm{Ne}$ yazık ki, fiks ilaç döküntüsü tedavisi sırasında hasta vefat etti.

Anahtar Sözcükler: illaç yan etki, antitüberküloz ilaç, ilaç döküntüsü, tüberküloz.
Tuberculosis (TB) is still a health problem in the world, and one of the leading causes of morbidity and mortality, particularly in developing countries in Asia and Africa. First-line anti-TB therapy with rifampin, isoniazid, pyrazinamide, ethambutol, and streptomycin is still very effective for pulmonary TB. However, adverse drug reaction (ADR) may complicate anti-TB treatment. Fixed drug eruption (FDE) is part of cutaneous ADR (CADR), which may be related to anti-TB drugs (1). FDE has been reported with rifampin, isoniazid, and ethambutol singly in some case reports (2-4). Presently described is rare case of pulmonary TB with FDE to all first-line anti-TB therapy.

Department of Pulmonology and Respiratory Medicine, Indonesia University, Jakarta, Indonesia

Endonezya Üniversitesi, Göğüs Hastalıkları Servisi, Jakarta, Endonezya

Submitted (Başvuru tarihi): 12.12.2016 Accepted (Kabul tarihi): 22.02.2017

Correspondence (iletişim): Gina Amanda, Department of Pulmonology and Respiratory Medicine, Indonesia

University, Jakarta, Indonesia

e-mail: gina_amanda@ymail.com 


\section{CASE}

A 34-year-old male patient was admitted to our hospital with chief complain of shortness of breath and productive cough. He had been diagnosed as pulmonary tuberculosis at a private clinic 1 year before admission. Oral firstline anti-TB drugs (combination of rifampin, isoniazid, pyrazinamide, and ethambutol) had been administered, but blisters appeared all over his body 4 days after consuming the drugs. Three months later, challenge test with rifampin and isoniazid was performed in district hospital, and blisters arose on the skin. Challenge test was discontinued until skin lesions healed. Following month, challenge test with pyrazinamide alone was initiated. Once again, similar skin lesions appeared and test was halted. Challenge test performed a month later with ethambutol also resulted in appearance of blisters. He was then referred to our hospital. Challenge test was re-initiated in outpatient clinic with rifampin and then with streptomycin injection, but blisters still appeared after each drug was administered singly. Desensitization test was planned, but the patient was lost to follow up after about 2 months.

On physical examination, the patient was in moderately good general condition, respiratory rate was 32 breaths per minute, and oxygen saturation was $96 \%$ with oxygen flow of 3 liters per minute via nasal canula. Widespread erosion, crust, and hyperpigmentation were observed on the skin. Pulmonary auscultation revealed reduction of breath sounds in the left upper lung field and bronchovesicular sound with crackles in bilateral lung field.

Chest X-ray revealed bullae in the left upper lung field with diffuse infiltrates (Figure 1). Acid-fast bacilli of sputum were positive and Xpert MTB/RIF test (Cepheid, Inc., Sunnyvale, CA, USA) of sputum result was Mycobacterium tuberculosis sensitive with rifampin. Antinuclear antibody test and rheumatoid factor were also checked to eliminate possibility of autoimmune etiology and results were negative. HIV antibody test was also negative. Skin biopsy performed at outpatient clinic revealed epidermis with subepidermal bullae containing eosinophil, fibrotic dermis, and chronic inflammatory cells (Figure 2). Conclusion was bullous drug eruption and was managed with oral steroid and topical cream. Anti-TB drug desensitization was planned for after skin lesions healed, but the patient's condition deteriorated. He died as result of severe hypoxemia.

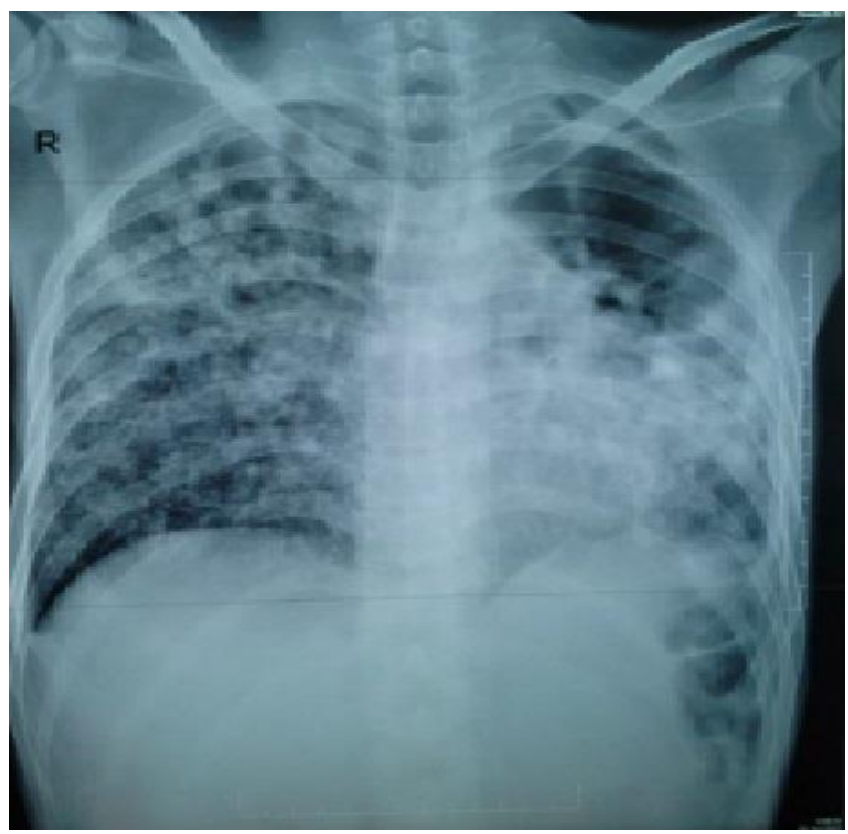

Figure 1: Chest $X$-ray revealed diffuse infiltrates with bullae in the upper left lung field

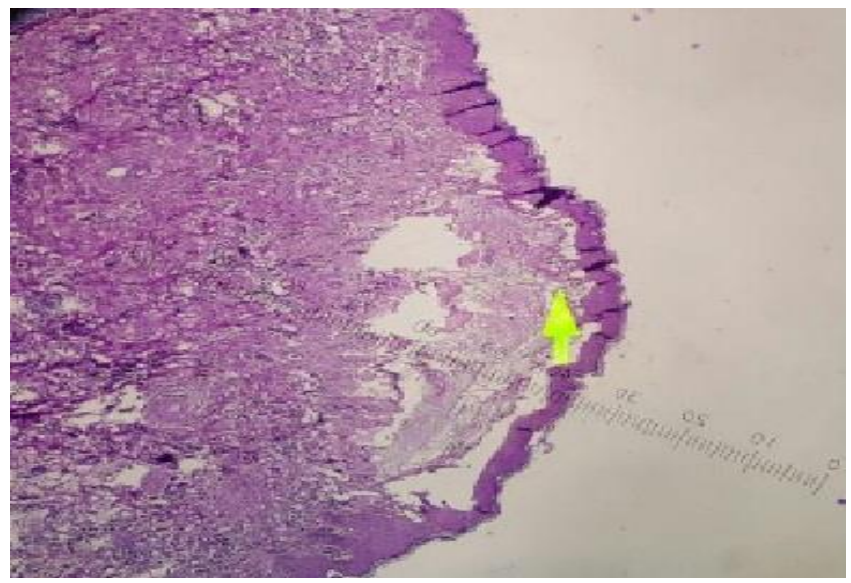

Figure 2: Histopathology examination of skin biopsy revealed subepidermal bullous (arrow) (H\&E x100)

\section{DISCUSSION}

The Anti-TB drugs used for pulmonary TB treatment are associated with ADR. ADR may include immunologicallymediated drug hypersensitivity (drug allergy) or nonimmune mediated/idiosyncratic reactions. Mechanism of drug allergy may be immunoglobulin $E(\mathrm{lg}-\mathrm{E})$ or non-lg-E mediated $(5,6)$. Anti-TB drugs contain low molecular compounds that may induce allergic reaction through antigen presenting cell (APC)-hapten binding. Hapten is a low molecular substance that binds to carrier, such as protein, before APC presentation. According to classification of Coombs and Gell, allergic reaction is divided into 4 types, and most reactions to low-molecular-weight drugs are type I and type IV (7). CADR is part of ADR and one of the most commonly observed side effects of antiTB drugs. There are several types of CADR, such as mor- 
biliform and maculopapular drug eruption, exfoliative dermatitis, lichenoid drug eruption, cutaneous vasculitis, FDE, Steven Johnson Syndrome, and toxic epidermal necrolysis (5). FDE has many variant forms of lesion, including solitary or small number of erythematous macules and widespread lesion with blisters. Lesion can appear on any part of the skin or mucous membranes within a day to a few weeks after administering the causative drug. It resolves with residual hyperpigmentation $(8,9)$. Generalized bullous drug eruption is severe form of FDE with mortality rate of $22 \%$ (10). In our patient, blisters appeared after administration of combination of anti-TB drugs and after challenge test with all anti-TB drugs. Diagnosis of FDE was confirmed by histopathology examination.

There are limited available data about incidence of antiTB drug related CADR. Severe CADR may result in discontinuation of anti-TB drug use and thereby increase morbidity and even mortality (1). Nahid et al. (11) found that HIV status, positive result of sputum smear at baseline, and drug interruption during intensive phase was associated with high mortality rate in TB patient. Severe FDE in our patient interrupted pulmonary TB treatment and time was required for healing of skin lesions before re-starting anti-TB drug administration. Poor outcome in this patient was related not only to severe FDE, but also to patient declining to continue therapy.

Reintroducing anti-TB treatment following TB-associated CADR is important to diminish mortality rate. There are 2 methods to this process: challenge and desensitization. Challenge test aims to identify the offending drug and eliminate it from the regimen of therapy, whereas desensitization seeks to relieve immune response to causal drug by prolonged or repeated stimulus. Neither is recommended for drugs that have been associated with severe allergic reaction. However, exclusion from challenge test can lead to high risk of death, so risk-benefit ratio should be considered before performing these tests on patient with severe allergic reaction (5).

Challenge test protocol may begin with isoniazid $50 \mathrm{mg}$ on day 1 . If there is no allergic reaction, the dose may be increased to $300 \mathrm{mg}$ on day 2 . This dose should continue for 4 days if allergic reaction does not occur. Drugs are then added in order and dose specified in Table 1. Dose of each drug is increased until recommended dose is achieved and is then continued for 4 days. If allergic reaction occurs during challenge test, desensitization test may be performed for the causative drug. General protocol for desensitization test may be initiated with $1 / 10$ of the day 1 dose. Each dose is doubled and administered twice daily until recommended daily dose has been achieved and it is continued for 3 days before it may be replaced by once daily dosing. If allergic reaction occurs during desensitization process, dose is decreased to the highest dose that did not cause any allergic reaction and increased in smaller increments (12).

Tablo 1: The Challenge Test Protocol

\begin{tabular}{|c|c|c|}
\hline Drug & \multicolumn{2}{|c|}{ Challenge Doses } \\
\hline & Day 1 & Day 2 \\
\hline Isoniazid & $50 \mathrm{mg}$ & $300 \mathrm{mg}$ \\
\hline Rifampicin & $75 \mathrm{mg}$ & $300 \mathrm{mg}$ \\
\hline Pyrazinamide & $250 \mathrm{mg}$ & $1000 \mathrm{mg}$ \\
\hline Ethambutol & $100 \mathrm{mg}$ & $500 \mathrm{mg}$ \\
\hline Streptomycin & $125 \mathrm{mg}$ & $500 \mathrm{mg}$ \\
\hline
\end{tabular}

In conclusion, CADR is one of possible side effects of anti-TB drugs. Severe reaction will interrupt pulmonary TB treatment for long period of time and will likely increase either complication of underlying disease or mortality risk. Re-introducing anti-TB drugs is required for patients with CADR before they continue anti-TB treatment. Although severe reaction in CADR is rare, it may be fatal. Close monitoring and proper management are needed for patient with this case.

\section{ACKNOWLEDGMENT}

We would like to express our sincere gratitude to Dr. Dianiati Kusumo Sutoyo of the Immunology division, Department of Pulmonology and Respiratory Medicine, Faculty of Medicine Universitas Indonesia, Persahabatan Hospital for her valuable advice and support for this case report, Dr. Euis Muthmainah of the Department of Dermatology and Venerology Persahabatan Hospital for her advice and support during the treatment of the patient and Dr. Ruth Emalian Sembiring of Department of Pathology Persahabatan Hospital for providing the microscopic histopatology figure.

\section{CONFLICTS OF INTEREST}

None declared.

\section{AUTHOR CONTRIBUTIONS}

Concept - G.A., F.N., F.I.; Planning and Design - G.A., F.N., F.I.; Supervision - G.A., F.N., F.I.; Funding - G.A., F.N.; Materials - G.A.; Data Collection and/or Processing - G.A.; Analysis and/or Interpretation - G.A., F.I.; 
Literature Review - G.A.; Writing - G.A.; Critical Review G.A., F.N.

\section{YAZAR KATKILARI}

Fikir - G.A., F.N., F.I.; Tasarım ve Dizayn - G.A., F.N., F.I.; Denetleme - G.A., F.N., F.I.; Kaynaklar - G.A., F.N.; Malzemeler - G.A.; Veri Toplama ve/veya İşleme - G.A.; Analiz ve/veya Yorum - G.A., F.I.; Literatür Taraması G.A.; Yazıyı Yazan - G.A.; Eleştirel İnceleme - G.A., F.N.

\section{REFERENCES}

1. Tan WC, Ong CK, Kang SC, Razak MA. Two years review of cutaneous adverse drug reaction from first line anti-tuberculous drugs. Med J Malaysia 2007; 62:143-6.

2. John SS. Fixed drug eruption due to rifampin. Lepr Rev 1998; 69:397-9. [CrossRef]

3. Scheid P, Kanny G, Trechot P, Rosner V, Menard O, Vignaud JM, et al. Isoniazid-induced bullous skin reaction. Allergy 1999; 54:294-6. [CrossRef]

4. Bakayoko AS, Kaloga M, Kamagate M, Kone Z, Daix AT, Ohui $E$, et al. Fixed drug eruption after taking ethambutol. Rev Mal Respir 2015; 32:48-51. [CrossRef]

5. Lehloenya RJ, Dheda K. Cutaneous adverse drug reactions to anti-tuberculosis drugs: state of the art and into the future. Expert Rev Anti Infec Ther 2012; 10:475-86. [CrossRef]
6. Thong BY, Tan TC. Epidemiology and risk factors for drug allergy. Br J Clin Pharmacol 2011; 71:684-700. [CrossRef]

7. Schnyder B, Brockow K. Pathogenesis of drug allergy current concepts and recent insights. Clin Exp Allergy 2015; 45:1376-83. [CrossRef]

8. Shiohara T. Fixed drug eruption: pathogenesis and diagnostic tests. Curr Opin Allergy Clin Immunol 2009; 9:316-21. [CrossRef]

9. Sehgal VN, Srivastava G. Fixed drug eruption (FDE): changing scenario of incriminating drugs. Int J Dermatol 2006; 45:897-908. [CrossRef]

10. Lipowicz S, Sekula P, Ingen-Housz-Oro S, Liss Y, Sassolas $B$, Dunant $A$, et al. Prognosis of generalized bullous fixed drug eruption: comparison with Stevens-Johnson syndrome and toxic epidermal necrolysis. Br J Dermatol 2013; 168:726-32. [CrossRef]

11. Nahid P, Jarlsberg LG, Rudoy I, de Jong BC, Unger A, Kawamura $L M$, et al. Factors associated with mortality in patients with drug-susceptible pulmonary tuberculosis. BMC Infec Dis 2011;11:1. [CrossRef]

12. Philadephia tuberculosis control program. Guidelines for the management of adverse drug effects of antimycobacterial agents. Philadelphia: Philadephia tuberculosis control program; 1998. p. 5-6. 